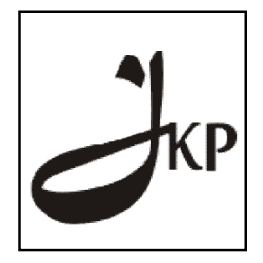

Jurnal Konseling dan Pendidikan

ISSN Cetak: 2337-6740 - ISSN Online: 2337-6880

http://jurnal.konselingindonesia.com

Volume 3 Nomor 3, November 2015, HIm 47-51

Info Artikel:

Diterima 11/10/2015

Direvisi 08/10/2015

Dipublikasikan $28 / 11 / 2015$

\title{
MELALUI PENDEKATAN KONTEKSTUAL UNTUK PENINGKATAN KETERAMPILAN MENDESKRIPSIKAN BINATANG DENGAN BAHASA TULIS MENGGUNAKAN MEDIA GAMBAR BINATANG PADA SISWA KELAS II SD NEGERI 26 NANGGALO TAHUN PELAJARAN 2014/2015
}

\section{WISNARLIS}

\begin{abstract}
Abstrak
Pembelajaran bahasa Indonesia berfungsi membantu peserta didik untuk mengemukakan gagasan dan perasaan, berpartisipasi dalam masyarakat dengan menggunakan bahasa tersebut, dan menemukan serta menggunakan kemampuan analitis dan imajinatif. Penelitian ini bertujuan untuk meningkatkan kemampuan siswa dalam Meningkatkan Keterampilan Mendeskripsikan Binatang Dengan Bahasa Tulis Menggunakan Media Gambar Binatang, Melalui Pendekatan Kontekstual. Penelitian ini menggunakan rancangan penelitian tindakan kelas (classromm-based action research). Hasil penelitian ini menunjukkan peningkatan dari siklus I dan siklus II. Siswa yang mengalami ketuntasan belajar sebanyak $35 \%$ setelah dilakukan tindakan ketuntasan belajar siswa naik menjadi $97 \%$. Temuan yang lain anak menjadi senang, percaya diri dalam melakukan proses pembelajaran. Dengan demikian dapat disarankan bahwa pelaksanaan pendidikan hendaknya berwawasan lingkungan karena lingkungan banyak menyediakan alat bantu yang murah, mudah didapat dan mudah dikenal anak.
\end{abstract}

Keyword: Pendekatan Kontekstual, Media Gambar Binatang; Bahasa Indonesia; SD

Copyright (C) 2015 IICET (Padang - Indonesia) - All Rights Reserved

Indonesian Institute for Counseling, Education and Theraphy (IICET)

\section{PENDAHULUAN}

Berbahasa dengan baik dan benar diperlukan pendidikan dan pembelajaran bahasa Indonesia. Pendidikan dan pembelajaran bahasa Indonesia merupakan salah satu aspek penting yang perlu diajarkan kepada siswa di sekolah. Bahasa memiliki peran sentral dalam perkembangan intelektual, sosial, dan emosional peserta didik dan merupakan penunjang keberhasilan dalam mempelajari semua bidang studi (BSNP, 2006). Oleh karena itu pemerintah membuat kurikulum bahasa Indonesia yang wajib untuk diajarkan kepada siswa pada setiap jenjang pendidikan, yakni dari tingkat Sekolah Dasar (SD) sampai dengan Perguruan Tinggi (PT). Pembelajaran bahasa Indonesia merupakan suatu tantangan tersendiri bagi seorang guru, mengingat bahasa ini bagi sebagian sekolah merupakan bahasa pengantar yang dipakai untuk menyampaikan materi pelajaran yang lain.

Pembelajaran bahasa Indonesia berfungsi membantu peserta didik untuk mengemukakan gagasan dan perasaan, berpartisipasi dalam masyarakat dengan menggunakan bahasa tersebut, dan menemukan serta menggunakan kemampuan analitis dan imajinatif (Depdiknas, 2007). Sesuai dengan kenyataan yang terjadi pada saat ini, mata pelajaran bahasa Indonesia sering diremehkan oleh sebagian besar siswa, bahkan dianggap sebagai mata pelajaran yang membosankan, khususnya dalam aspek menulis. Menurut Pantow dkk (2002) pada dunia pendidikan, menulis merupakan suatu tuntutan keterampilan yang harus dikuasai oleh manusia sebagai bahasa tulis. Oleh karena itu, sejak dini pembelajaran bahasa selalu didasarkan pada keterampilan bahasa dimana salah satunya adalah writing. Kesulitan siswa dalam menulis biasanya terlihat ketika siswa diminta untuk menulis sebuah karangan sederhana, mendeskripsikan suatu benda ataupun ketika menulis puisi, mereka sering mengeluh dan terlihat bingung dengan apa yang ingin mereka tulis.

Kebosanan, kejenuhan, serta kebingungan siswa dalam hal menulis yang mengakibatkan menurunnya prestasi belajar siswa dalam pembelajaran menulis dapat disebabkan oleh beberapa faktor, antara lain :

1) Kurangnya minat siswa terhadap kegiatan menulis.

2) Kurangnya motivasi siswa, baik dari dalam diri mereka maupun dari lingkungan belajar.

3) Pengembangan strategi pembelajaran yang kurang membangkitkan daya imajinasi siswa dan kreativitas siswa dalam berbahasa maupun bersastra. 
4) Media yang digunakan dalam pembelajaran yang kurang sesuai sehingga siswa kurang bersemangat dalam belajar.

Menurunnya prestasi belajar siswa dapat dibuktikan dengan hasil tes pada mata pelajaran Bahasa Indonesia aspek menulis pada tanggal 15 Januari 2015, dengan tujuan pembelajaran mendeskripsikan binatang dengan bahasa tulis menggunakan media gambar yang dilaksanakan pada siswa kelas II SD Negeri 26 Nanggalo. Dari tes tersebut diperoleh hasil tulisan siswa belum sempurna, karena penggunaan katanya belum tepat dan kalimatnya cenderung diulang-ulang sehingga tidak mudah untuk dipahami. Perolehan nilai rata-rata kelas yang seharusnya mencapai angka di atas 70 , pada kenyatannya hanya mencapai angka 65 , sehingga hanya $27 \%$ siswa yang memenuhi Kriteria Ketuntasan Minimal (KKM) bahasa Indonesia dalam aspek menulis untuk kelas II semester II SD Negeri 26 Nanggalo.

Permasalahan yang telah diuraikan sebelumnya, harus diantsipasi oleh guru dengan menggunakan suatu pendekatan atau model pembelajaran yang efektif, inovatif, dan berpotensi memperbaiki pembelajaran menulis, sehingga meningkatkan minat, motivasi, dan sikap siswa terhadap pembelajaran menulis yang berakibat pada meningkatnya prestasi belajar siswa. Dengan demikian guru dapat merancang suatu bentuk pembelajaran yang aktif, kreatif, efektif, dan menyenangkan melalui pendekatan kontekstual dengan media gambar sebagai media alternatif dalam pemecahan masalah tersebut. Pendekatan kontekstual (Contextual Teaching and Learning) merupakan konsep belajar yang membantu guru mengaitkan antara materi yang diajarkannya dengan situasi dunia nyata siswa dan mendorong siswa membuat hubungan antara pengetahuan yang dimilikinya dengan penerapannya dalam kehidupan mereka sebagai anggota keluarga dan masyarakat (Dikdasmen Dikdas, 2002:1). Media gambar dimaksudkan untuk memudahkan siswa dalam mendeskripsikan seekor binatang dengan bahasa tulis. Media gambar digunakan dalam penelitian ini karena pola berpikir siswa kelas II yang masih memerlukan media pembelajaran yang konkrit.

Rumusan masalah penelitian ini adalah bagaimanakah pendekatan kontekstual dengan menggunakan media gambar binatang dapat meningkatkan keterampilan mendeskripsikan binatang yang ada di sekitar dengan bahasa tulis bagi siswa kelas II SD Negeri 26 Nanggalo? Tujuan penelitian ini untuk menggambarkan pendekatan kontekstual dengan menggunakan media gambar binatang dapat meningkatkan keterampilan mendeskripsikan binatang yang ada di sekitar dengan bahasa tulis bagi siswa kelas II SD Negeri 26 Nanggalo.

\section{METODOLOGI PENELITIAN}

Penelitian ini menggunakan rancangan penelitian tindakan kelas (classromm-based action research) dengan tahapan perencanaan, pelaksanaan, observasi dan refleksi (Aqib:2006; PTK:2008). Penelitian Tindakan Kelas dilaksanakan selama dua siklus. Pembelajaran dilakukan di kelas II SD Negeri 26 Nanggalo Kecamatan Koto XI Tarusan, Kabupaten Pesisir Selatan. Subjek penelitian tindakan ini adalah siswa-siswi kelas II SD Negeri 26 Nanggalo Kecamatan Koto XI Tarusan, Kabupaten Pesisir Selatan, berjumlah 22 siswa.

\section{HASIL DAN PEMBAHASAN PENELITIAN HASIL PENELITIAN \\ Siklus I \\ Perencanaan}

Peneliti melakukan perencanaan tindakan dengan membuat Rencana Pelaksanaan Pembelajaran (RPP). Pembelajaran yang direncanakan menggunakan media atau alat bantu pembelajaran berupa gambar ilustrasi tentang bintang yang ada di lingkungan sekitar yang dapat dilihat oleh semua siswa. Peneliti mempersiapkan lembar observasi mengenai aktivitas siswa pada saat pembelajaran serta lembar penilaian hasil karya siswa.

\section{Pelaksanaan}

Pada siklus ini peneliti menggunakan konsep belajar secara individu untuk mengetahui tingkat kemampuan masing-masing siswa dengan menggunakan media gambar melalui pendekatan kontekstual. Pelaksanaannya dilakukan selama dua pertemuan. Prosedur pelaksanaannya sebagai berikut :

- Peneliti menayangkan gambar.

- Siswa mulai memperhatikan gambar dan mengamati hal-hal yang ada dalam gambar.

- Siswa mulai mendeskripsikan binatang yang terdapat dalam gambar dengan menyebutkan ciri-cirinya secara lengkap. 
- Dalam kegiatan tersebut peneliti memberikan kesempatan kepada siswa untuk bertanya dengan semua warga kelas.

- Peneliti memberikan arahan dan timbal balik kepada siswa yang bertanya sehingga imajinasi siswa semakin kompleks.

- Siswa membacakan hasil tulisannya di depan kelas.

- Siswa lain mendengarkan.

- Peneliti memotivasi siswa dengan cara memberikan penguatan verbal berupa kata-kata dan non verbal berupa tepuk tangan.

- Siswa memajangkan karyanya di tempat yang telah disediakan.

- Sebagai akhir pembelajaran guru menyanyikan lagu "bebek-bebekku".

Observasi

Observasi dilakukan dengan menggunakan lembar observasi yang berupa check list untuk mengetahui sejauh mana minat siswa dalam mengikuti pembelajaran dengan motivasi-motivasi yang diberikan guru, untuk mengetahui aktivitas siswa dalam pembelajaran, serta tingkat keterampilan dan daya imajinasi siswa dalam menulis, mengetahui kemahiran siswa dalam mengolah kata-kata sehingga menjadi sebuah tulisan yang runtut, dengan teknik penyajian yang sesuai.

\section{Refleksi}

Peneliti membuat analisis data untuk mengetahui tingkat keberhasilan tindakan pada siklus I sebagai acuan untuk pelaksanaan pada siklus berikutnya.

\section{Siklus II}

\section{Perencanaan}

Peneliti melakukan perencanaan tindakan dengan membuat Rencana Pelaksanaan Pembelajaran (RPP) dengan kompetensi dasar mendeskripsikan tumbuhan dan binatang di sekitar secara sederhana dengan bahasa tulis. Pada siklus ini, peneliti menggunakan media atau alat bantu pembelajaran berupa puzzle (potongan gambar) tentang seekor binatang untuk masing-masing kelompok. Siklus II menggunakan konsep pembelajaran dalam bentuk kelompok. Hal itu dimaksudkan untuk mengetahui interaksi siswa dengan siswa. Peneliti juga menyediakan kertas undian untuk mengambil puzzle yang telah disediakan. Sebagai alat untuk memotivasi siswa dalam meningkatkan prestasi belajar Bahasa Indonesia guru menyediakan piagam penghargaan untuk kelompok yang memiliki predikat kelompok Top 1, kelompok Top 2, dan kelompok Top 3.

\section{Pelaksanaan}

Pelaksanaan dilakukan selama dua pertemuan dengan konsep pembelajaran secara kelompok. Prosedur pelaksanaannya adalah sebagai berikut :

a) Peneliti menyediakan media pembelajaran yang berupa puzzle tentang gambar binatang yang ada di sekitar dan kertas undian untuk mengambil gambar.

b) Siswa dipersiapkan untuk duduk secara berkelompok sesuai dengan kelompok yang telah dibentuk.

c) Sebelum memulai pembelajaran, siswa memberi nama untuk masing-masing kelompoknya dengan nama binatang yang disukai.

d) Siswa memberikan alasan tentang pemberian nama pada kelompoknya.

e) Setiap kelompok membuat yel-yel, kemudian diucapkan.

f) Setiap kelompok mengambil puzzle sesuai dengan undian.

g) Siswa dalam kelompoknya menyusun puzzle (potongan gambar) kemudian mengamati gambar yang telah terbentuk.

h) Siswa menuliskan deskripsi tentang binatang dalam gambar yang diamati, misalnya dengan menyebutkan ciricirinnya secara lengkap.

i) Dalam kegiatan itu, guru terus memantau kerja siswa seraya memberikan arahan-arahan yang diperlukan siswa.

j) Setelah selesai menuliskan deskripsinya, siswa membuat kalimat-kalimat tentang ciri-ciri binatang yang harus ditebak oleh kelompok lain.

k) Hasil karya siswa dibacakan di depan kelas oleh perwakilan tiap kelompok.

1) Guru bersama siswa menentukan kelompok-kelompok yang yang berhak mendapatkan penghargaan.

m) Guru memberikan penghargaan kepada kelompok yang berhak dalam bentuk piagam dan tanda bintang.

n) Siswa memajangkan hasil karyanya ditempat yang telah disediakan. 


\section{Observasi}

Observasi dilakukan dengan menggunakan lembar observasi yang berupa check list untuk mengetahui sejauh mana minat siswa dalam mengikuti pembelajaran dengan motivasi-motivasi yang diberikan guru, untuk mengetahui aktifitas siswa dalam pembelajaran, aktifitas siswa dalam kelompok, serta tingkat keterampilan dan daya imajinasi siswa dalam menulis, dan untuk mengetahui kemahiran siswa dalam mengolah kata-kata sehingga menjadi sebuah tulisan yang runtut, dengan teknik penyajian yang sesuai.

\section{Refleksi}

Peneliti membuat analisis data untuk mengetahui tingkat keberhasilan tindakan pada siklus II sebagai acuan untuk pelaksanaan pada siklus berikutnya jika memang diperlukan.

Hasil belajar dari dua siklus penelitian dapat di gambarkan berikut ini.

Tabel 1

Rekapitulasi ketuntasan hasil belajar

\begin{tabular}{|l|c|c|c|c|}
\hline \multirow{2}{*}{ No } & \multicolumn{2}{|c|}{ Siklus I } & \multicolumn{2}{c|}{ Siklus II } \\
\cline { 2 - 5 } & Nilai & Keterangan & Nilai & Keterangan \\
\hline $\mathrm{N}-01$ & 60 & Tidak Tuntas & 70 & Tuntas \\
\hline $\mathrm{N}-02$ & 70 & Tuntas & 80 & Tuntas \\
\hline $\mathrm{N}-03$ & 90 & Tuntas & 90 & Tuntas \\
\hline $\mathrm{N}-04$ & 70 & Tuntas & 80 & Tuntas \\
\hline $\mathrm{N}-05$ & 55 & Tidak Tuntas & 60 & Tidak Tuntas \\
\hline $\mathrm{N}-06$ & 65 & Tuntas & 75 & Tuntas \\
\hline $\mathrm{N}-07$ & 65 & Tuntas & 60 & Tidak Tuntas \\
\hline $\mathrm{N}-08$ & 65 & Tuntas & 75 & Tuntas \\
\hline $\mathrm{N}-09$ & 70 & Tuntas & 80 & Tuntas \\
\hline $\mathrm{N}-10$ & 65 & Tuntas & 70 & Tuntas \\
\hline $\mathrm{N}-11$ & 65 & Tuntas & 80 & Tuntas \\
\hline $\mathrm{N}-12$ & 70 & Tuntas & 80 & Tuntas \\
\hline $\mathrm{N}-13$ & 75 & Tuntas & 90 & Tuntas \\
\hline $\mathrm{N}-14$ & 70 & Tuntas & 80 & Tuntas \\
\hline $\mathrm{N}-15$ & 60 & Tidak Tuntas & 70 & Tuntas \\
\hline $\mathrm{N}-16$ & 70 & Tuntas & 80 & Tuntas \\
\hline $\mathrm{N}-17$ & 90 & Tuntas & 90 & Tuntas \\
\hline $\mathrm{N}-18$ & 70 & Tuntas & 80 & Tuntas \\
\hline $\mathrm{N}-19$ & 55 & Tidak Tuntas & 60 & Tidak Tuntas \\
\hline $\mathrm{N}-20$ & 65 & Tuntas & 75 & Tuntas \\
\hline $\mathrm{N}-21$ & 90 & Tuntas & 90 & Tuntas \\
\hline $\mathrm{N}-22$ & 70 & Tuntas & 80 & Tuntas \\
\hline
\end{tabular}

Berdasarkan tabel di atas terlihat peningkatan hasil belajar yang dicapai oleh siswa. masih ada siswa yang hasil belajarnya menurun. Hal ini disebabkan kesehatan siswa tersebut kurang baik.

\section{PEMBAHASAN}

Metodologi pengajaran bahasa Indonesia, menyebutkan bahwa bahasa memungkinkan manusia untuk saling berhubungan (berkomunikasi), saling berbagi pengalaman, saling belajar dari orang lain, memahami orang lain, menyatakan diri, dan meningkatkan kemampuan intelektual (Ngalim Purwanto :1997:4; Umar, A. Rozaq, 
dkk. 2004). Berkomunikasi ini dapat dilakukan melalui lisan dan tertulis. Keterampilan menulis tidak dapat dimiliki oleh siswa dengan mudah. Menulis merupakan keterampilan oleh karena itu diperlukan latihan-latihan yang berkelanjutan dan terus-menerus (Alfianto:2006; Artati:2004). Tujuan yang diharapkan dalam pembelajaran menulis adalah agar siswa mampu mengungkapkan gagasan, pendapat, pengetahuan secara tertulis serta memiliki kegamaran menulis (Depdikbud, 1994).

Menulis deskripsi dapat dilakukan dengan cara menuliskan kalimat-kalimat deskripsi dari gambar-gambar yang mereka miliki. Kegiatan menulis deskripsi ini dapat merangsang anak untuk mengungkapkan suatu bentuk/benda yang dipahami anak melalui tulisan (Arya yanti, 2007; Wijayanti, Ari, 2007) http://www.sabda.org. Anak-anak dapat diminta untuk menulis kalimat-kalimat deskripsi dari gambar-gambar (sesuai dengan materi pelajaran yang disampaikan) yang dipasang di kelas. Untuk me-review, anak-anak dapat diminta untuk memasangkan kalimat-kalimat itu sesuai dengan gambar-gambar tersebut. Sebagai kreasi dalam pelajaran, anakanak dapat menulis deskripsi tentang binatang-binatang dan memasangkannya dengan foto binatang yang tersedia (PEPAK SABDA, 2002) yang teredia dalam http://pepak.sabda.org.

\section{KESIMPULAN DAN SARAN \\ KESIMPULAN}

Pendekatan kontekstual dengan menggunakan media gambar dapat meningkatkan keterampilan mendeskripsikan binatang dengan bahasa tulis pada siswa kelas II SD Negeri 26 Nanggalo.

\section{SARAN}

Untuk meningkatkan kualitas pendidikan khususnya pembelajaran Bahasa Indonesia di kelas rendah ada yang harus dilakukan guru yaitu penggunaan media yang menarik dan pendekatan yang sesuai dengan materi sehingga siswa senang dan tidak membosankan selain bimbingan dan latihan.

\section{DAFTAR PUSTAKA}

Alfianto, Achmad, 2006. Pelajaran Bahasa Indonesia di Sekolah, Metamorfosis Ulat menjadi Kepompong. Artikel Pendidikan Network, (Online), (http://re-researchengines.com, diakses 24 Oktober 2007).

Aqib, Zainal, 2006. Penelitian Tindakan Kelas untuk Guru. Bandung: Yrama Widya.

Artati. Y. Budi, 2004. Pelajaran Bahasa dan Sastra Indonesia. Klaten : Intan Pariwara.

Arya Yanti, Puji, 2007. Menumbuhkan Budaya Menulis pada Anak. (Online), (http://www.sabda.org, diakses 24 Februari 2008).

BSNP, 2006. Standar Kompetensi dan Kompetensi Dasar SD/MI. Jakarta : Badan Standar Nasional Pendidikan.

Depdiknas, 2007. Pembelajaran Aktif Kreatif, Efektif dan Menyenangkan. (Online), (http://farhanzen.wordpress.com, diakses 15 Januari 2008).

Dikdasmen Diknas, 2002. Pendekatan Kontekstual (Contextual Teaching and Learning (CTL)). Jakarta: Depdiknas.

Pantow, Johana, dkk, 2002. Analisa kemampuan menulis Bahasa Inggris Mahasiswa FKIP-UT. (Online), (http://digilib.itb.ac.id, diakses 26 januari 2008).

PTK, 2008. Salah Satu Contoh PTK dalam Bidang Bahasa, (Online), (http://aflahchintya23.wordpress.com, diakses 10 Maret 2008)

Purwanto, M. Ngalim, 1997. Metodologi Pengajaran Bahasa Indonesia di Sekolah Dasar. Jakarta: Rosda Jayaputra.

Pepak, 2002. Aktivitas Menulis, (Online), (http://pepak.sabda.org, diakses 10 Maret 2008).

Umar, A. Rozaq, dkk. 2004. Bahasa dan Sastra Indonesia Kelas 2 SD dan MI. Klaten : Sahabat.

Wijayanti, Ari, 2007. Pengajaran Bahasa Indonesia yang Efektif. Portal Dunia Guru, (Online), (http://lubisgrafura.wordpress.com, diakses 24 Oktober 2007). 